\title{
ENHANCING STUDENTS' ACADEMIC PERFORMANCE IN MALAYSIAN ONLINE DISTANCE LEARNING INSTITUTIONS
}

\section{Zahir Osman*, Wardah Mohamad, Ratna Khuzaimah Mohamad, Liana Mohamad and Tuan Fatma Tuan Sulaiman}

Cluster of Business Management, Bangi Learning Centre, Open University Malaysia, Jalan 7/7B, Seksyen 7, 43650 Bandar Baru Bangi, Bangi, Selangor, Malaysia

*Corresponding author: zahir_osman@oum.edu.my

Publication date: 31 March 2019

To cite this article: Zahir Osman, Wardah Mohamad, Ratna Khuzaimah Mohamad, Liana Mohamad, \& Tuan Fatma Tuan Sulaiman. (2018). Enhancing students' academic performance in Malaysian online distance learning institutions. Asia Pacific Journal of Educators and Education, 33, 19-28. https://doi.org/10.21315/apjee2018.33.2

To link to this article: https://doi.org/10.21315/apjee2018.33.2

\begin{abstract}
The increasing number of learner failure rates are alarming in online distance learning. Previous studies have identified the factors that have contributed to online distance learning students' failure as lack of time and lack of motivation. The purpose of this study is to develop a direct effect understanding of extrinsic motivation, intrinsic motivation, self-efficacy and time management on students' academic performance in an online distance learning institution in Malaysia. The Structural Equation Model (SEM) was used to analyse the casual relationships between independent variables and dependent variables. The model was developed and later tested by adopting the Partial Least Square (PLS) procedure on data collected from a survey that yielded 210 usable questionnaires. The findings showed that extrinsic motivation, intrinsic motivation, self-efficacy and time management have a significant and positive influence on students' academic performance in an online distance learning institution. The findings imply that the relationship amongst extrinsic motivation, intrinsic motivation, self-efficacy and time management on a student's academic performance in an online distance learning institution will lead to the online distance learning institution's low attrition rate. This study uses SmartPLS 2.0 and SPSS 18.0 to test the hypothesis and analyse respondents' profile, respectively.
\end{abstract}

Keywords: student performance, extrinsic motivation, intrinsic motivation, self efficacy, time management

(C) Penerbit Universiti Sains Malaysia, 2019. This work is licensed under the terms of the Creative Commons Attribution (CC BY) (http://creativecommons.org/licenses/by/4.0/). 


\section{INTRODUCTION}

Academic success is deemed very important amongst students who pursue their higher education. A higher education institution's performance will usually be gauged by its retention rates and the students' results. Therefore, if the students' failure rate is too high, eventually it will affect the image and the performance of the higher education institution. The effectiveness of online distance learning has been explained in many studies (Jung \& Rha, 2000; Olson \& Wisher, 2002). However, the increasing numbers of learner failure rates are alarming in online distance learning (Carr, 2000; Dalton, Manning, Hagen, Paul, \& Tong, 2000). Furthermore, a high failure rate among students will be even worse due to the latest government decision to raise the enrolment rate and broaden access to education, at the same time cutting financial support to the higher education sector. The main purpose of this study is to look at how intrinsic motivation, extrinsic motivation, self efficacy and time management influence students' performance in online distance learning and therefore offers a perspective of how these factors influence the performance of the students in their studies.

\section{LITERATURE REVIEW}

Online distance learning has gone through considerable change for more than a decade (Larreamendy-Joerns \& Leinhardt, 2006). The internet and many related technologies has caused online teaching and learning to merge into university regular practices. Simultaneously, it has also allowed the distance education to gain new appeal (Tallent-Runnels et al., 2006). According to Bates (2005), online learning is deemed to be a distance education subcategory that utilises the World Wide Web and internet. Online distance learning has gained popularity over the years and is being used by education institutions in many countries to give opportunities and meet the desires of student population growth and increase (Rumble \& Latchem, 2004). Miltiadou and Savenye (2003) found that studies on online distance learning environments and motivation have utilised many frameworks (e.g., Artino, 2008; Shroff, Vogel, Coombes, \& Lee, 2007; Yukselturk \& Bulut, 2007). In many of these studies, intrinsic-extrinsic motivation theory has been adopted to discover the reasons why students engage in online learning environments (e.g., Martens, Gulikers, \& Bastiaens, 2004; Xie, DeBacker, \& Ferguson, 2006). A famous theory that explains intrinsic-extrinsic motivation in detail is self-determination theory, SDT (Deci \& Ryan, 2000). Self-determination theory is a modern theory of situated motivation that is constructed on the foundation of learner autonomy. Intrinsic motivation is a very powerful source in our lives and can often produce fast results (Gallo \& Ronaldo, 2011). Students who have strong intrinsic motivation usually 
seek success for the sake of achieving it. In reality, if they believe they are forced to accomplish success in activities in which they are already interested in, their motivation level or inner interest is decreased. Bandura (1986) defined self efficacy as the personal confidence in a person and the capability to complete specific task successfully. Self-efficacy beliefs are important influential elements to determine an individual's ability to use effort on tasks and continuously deal with difficulties. As Bandura (1986) suggested, a person's beliefs about his capabilities constitute the person's self-efficacy. Time management can be defined by how an individual organises, schedules and budgets his or her time in order to generate effective work and increase productivity. It is based on priority - how an individual allocates and distributes his time towards competing tasks.

The following are the research hypotheses tested in this study:

H1: There is a positive and significant relationship between extrinsic motivation and student performance.

$\mathrm{H} 2$ : There is a positive and significant relationship between intrinsic motivation and student performance.

H3: There is a positive and significant relationship between self-efficacy and student performance.

H4: There is a positive and significant relationship between time management and student performance.

\section{METHODOLOGY}

The scaling applied on independent variables in this study is the 5-point Likert scale of 1 (strongly agree), 2 (agree), 3 (neutral), 4 (disagree) and 5 (strongly disagree). Online distance learning students who are studying in the diploma, bachelor and postgraduate programmes were the main respondents in the study. A total of 300 online distance learning students were requested to complete a questionnaire that contained measures of the construct. The questionnaires were distributed to the respondents in the Klang Valley on the spot by using convenient sampling technique. Out of the 300 distributed questionnaires, 226 were returned. The Mahalanobis analysis was successful in identifying the multivariate outliers which were deleted permanently, leaving 210 datasets to be used for further analysis. The software used was the SmartPLS 2.0 (Ringle, Wende, \& Will, 2005) and SPSS ver. 18. 


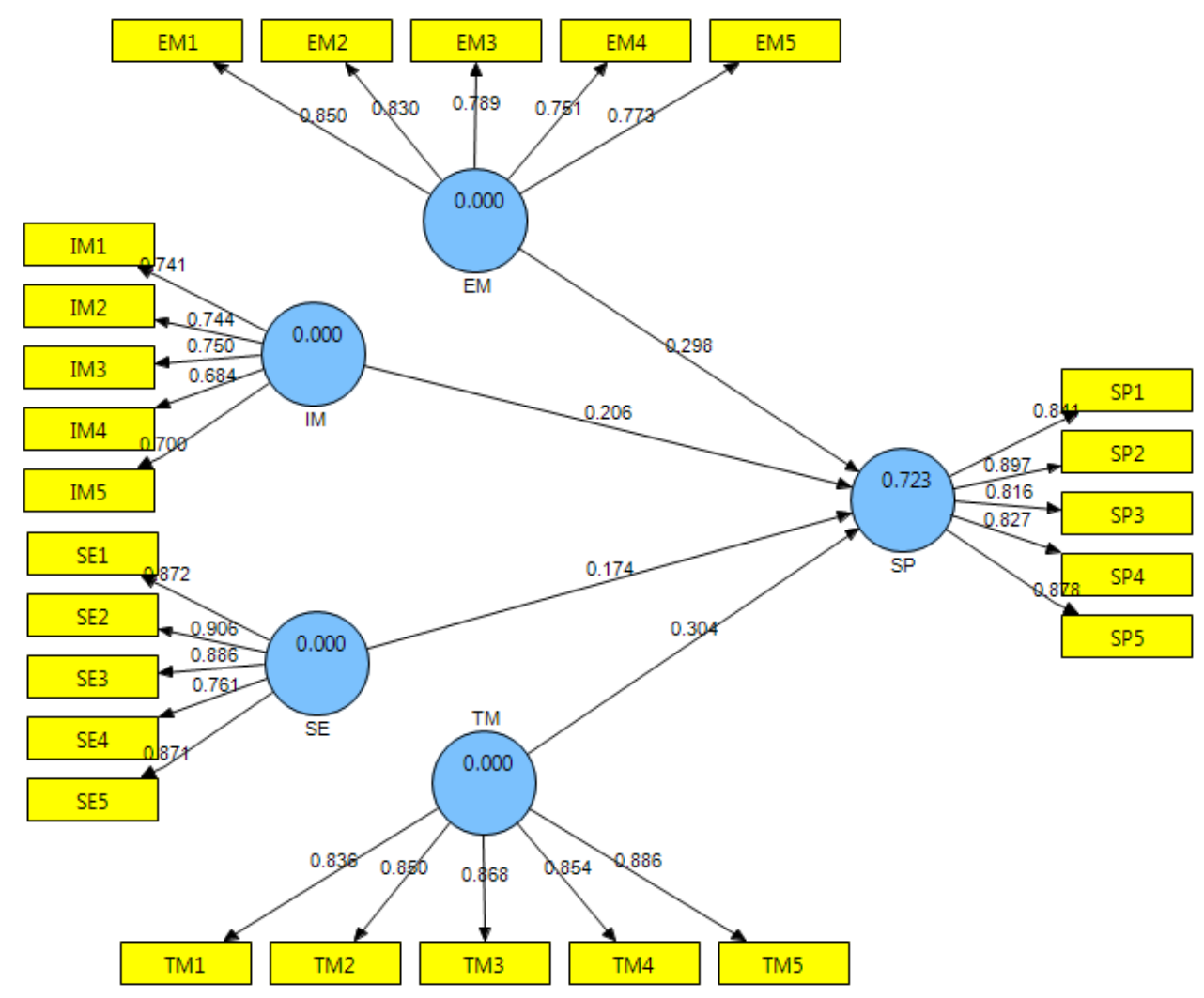

Figure 1. Research model and path coefficient

\section{RESULTS AND DISCUSSION}

\section{Model Measurement}

The measurement sufficiency models and the inner model predictive relevance, and test of the four hypotheses were assessed by SmartPLS. Partial Least Square (PLS) focuses on the explanation of variance using ordinal least squares, a technique suitable for relationships such as mentioned in this study (Gudergan, Ringle, Wende, \& Will, 2008). The adequacy and significance of reflective outer measurement models for the other constructs were evaluated through a range of indices test including of individual indicator weights and loadings, composite reliability, average variance explained (AVE), bootstrap $t$-statistic (critical ratio), discriminant validity and convergent validity. 
Table 1. Construct validity and reliability

\begin{tabular}{lccccc}
\hline & $\begin{array}{c}\text { Average variance } \\
\text { extracted (AVE) }\end{array}$ & $\begin{array}{c}\text { AVE square } \\
\text { root }\end{array}$ & $\begin{array}{c}\text { Composite } \\
\text { reliability }\end{array}$ & $R$-square & $\begin{array}{c}\text { Cronbach } \\
\text { alpha }\end{array}$ \\
\hline EM & 0.639 & 0.799 & 0.898 & 0.000 & 0.859 \\
$\mathrm{IM}$ & 0.525 & 0.724 & 0.846 & 0.000 & 0.779 \\
$\mathrm{SE}$ & 0.741 & 0.861 & 0.934 & 0.000 & 0.911 \\
$\mathrm{SP}$ & 0.727 & 0.852 & 0.930 & 0.723 & 0.906 \\
$\mathrm{TM}$ & 0.738 & 0.859 & 0.934 & 0.000 & 0.911 \\
\hline
\end{tabular}

Notes: EM = Extrinsic Motivation; IM = Intrinsic Motivation; $\mathrm{SE}=$ Self-Efficacy; $\mathrm{SP}$ = Student Performance; $\mathrm{TM}=$ Time Management.

As demonstrated in Table 1, all constructs composite reliabilities and their first-order factors range from 0.846 to 0.934 . Additionally, the significance of reflective outer-measurement model significance was evaluated by computing bootstrapped $t$-values critical ratio. The reflective outer-measurement models established acceptable bootstrap critical ratios conforming to the recommended 1.96 benchmark.

\section{Convergent Validity}

Composite reliability computation was used to evaluate the adequacy of outermeasurement models convergent validity (Hulland, 1999). The outer measurement models were used to confirm the analysis for convergent validity results and their first-order factors in line with Nunnally's (1978) reliability criteria, 0.70. As demonstrated in Table 1, all constructs composite reliabilities and their first-order factors ranged from 0.846 to 0.934 . Therefore, the constructs linked with outermeasurement models showed satisfactory convergent validity.

\section{Discriminant Validity}

Discriminant validity of the constructs was evaluated in three ways. Fornell and Larcker (1981) suggested the use of AVE, which indicates that discriminant validity existed if the square root of the AVE is greater than all corresponding correlations. As shown in Table 2, the square roots of the AVE values are steadily greater than the off-diagonal correlations, signifying discriminant validity at the construct level. An assessment of Table 3 shows that no single correlation (ranged from 0.551 to 0.784 ) was higher than their respective AVE (ranged from 0.724 to 0.861 ), thus demonstrating all constructs satisfactory discriminant validity. 
Table 2. Variable correlation matrix based on AVE square root

\begin{tabular}{lccccc}
\hline & EM & IM & SE & SP & TM \\
\hline EM & 0.799 & & & & \\
IM & 0.551 & $\mathbf{0 . 7 2 4}$ & & & \\
SE & 0.636 & 0.610 & $\mathbf{0 . 8 6 1}$ & & \\
SP & 0.746 & 0.664 & 0.723 & $\mathbf{0 . 8 5 2}$ & \\
TM & 0.736 & 0.618 & 0.769 & 0.784 & $\mathbf{0 . 8 5 9}$ \\
\hline
\end{tabular}

Notes: $\mathrm{EM}=$ Extrinsic Motivation; IM = Intrinsic Motivation; $\mathrm{SE}=$ Self-Efficacy; $\mathrm{SP}=$ Student Performance; $\mathrm{TM}=$ Time Management.

Table 3. Path coefficient and $t$-value

\begin{tabular}{lcc}
\hline & Path & $t$-value \\
\hline $\mathrm{EM} \rightarrow \mathrm{SP}$ & 0.298 & 6.088 \\
$\mathrm{IM} \rightarrow \mathrm{SP}$ & 0.206 & 3.852 \\
$\mathrm{SE} \rightarrow \mathrm{SP}$ & 0.174 & 3.344 \\
$\mathrm{TM} \rightarrow \mathrm{SP}$ & 0.304 & 5.022 \\
\hline
\end{tabular}

Notes: $\mathrm{EM}=$ Extrinsic Motivation; $\mathrm{IM}=$ Intrinsic Motivation; $\mathrm{SE}=$ Self-Efficacy; $\mathrm{SP}=$ Student Performance; $\mathrm{TM}=$ Time Management.

Table 4. Hypotheses result

\begin{tabular}{lccc}
\hline Hypothesis relationship & $\begin{array}{c}\text { Path } \\
\text { coefficient }\end{array}$ & $t$-value & Conclusion \\
\hline $\begin{array}{l}\text { H1: There is a positive and significant relationship } \\
\text { between extrinsic motivation and student } \\
\text { performance. }\end{array}$ & 0.298 & 6.088 & Supported \\
$\begin{array}{l}\text { H2: There is a positive and significant relationship } \\
\quad \begin{array}{l}\text { between intrinsic motivation and student } \\
\text { performance. }\end{array}\end{array}$ & 0.206 & 3.852 & Supported \\
$\begin{array}{l}\text { H3: } \begin{array}{l}\text { There is a positive and significant relationship } \\
\text { between self-efficacy and student performance. }\end{array} \\
\begin{array}{l}\text { H4: There is a positive and significant relationship } \\
\text { between time management and student performance. }\end{array}\end{array}$ 0.174 & 3.344 & Supported \\
\hline
\end{tabular}

H1 states that extrinsic motivation is predicted to have a positive influence on student performance. Table 4 results confirmed this hypothesis with a path coefficient of 0.298 and $t$-value of 6.088. In $\mathrm{H} 2$, student performance is predicted to be positively influenced by intrinsic motivation and the results in Table 4 supported $\mathrm{H} 2$ with the path coefficient of 0.206 and the $t$-value of 3.852. In H3, student performance is predicted to be positively influenced by self efficacy and 
results in Table 4 supported $\mathrm{H} 3$ with the path coefficient of 0.174 and the t-value of 3.344. Lastly, in H4, student performance is predicted to be positively influenced by time management and results in Table 4 supported $\mathrm{H} 4$ with the path coefficient of 0.304 and the $t$-value of 5.022 .

This research was conducted to determine the possible causal relationship among the variables, namely intrinsic motivation, extrinsic motivation, self efficacy and time management and students' performance. In relation to this, the review of the previous study in the area of intrinsic motivation, extrinsic motivation, self efficacy and time management and students' performance was done. From the academic studies initial findings, the model was developed and it revealed that intrinsic motivation, extrinsic motivation, self efficacy and time management have a positive and significant direct effect on a student's performance. It is not enough to determine the validity of a model theoretically and therefore empirical testing was done. This study proposed a model to empirically test and validate that there are positive direct relationships amongst extrinsic motivation, intrinsic motivation, self efficacy and time management on student's performance. The PLS data analysis technique was used to attain this objective. The findings showed that the most accepted relationship between intrinsic motivation and students' performance was verified. The direct relationship between extrinsic motivation and students' performance path coefficient is 0.298 and the critical ratio $t$-value is 6.088 which is significant. Secondly, the direct relationship connects intrinsic motivation and students' performance was also well supported with the path coefficient of 0.206 and the critical ratio $t$-value of 3.852 which is significant. Thirdly, the relationship between selfefficacy and students' performance was verified. The direct relationship between the self efficacy and students' performance path coefficient is 0.174 and the critical ratio $t$-value is 3.344 which are significant. Lastly, the relationship between time management and students' performance was verified. The direct relationship between self efficacy and students' performance path coefficient is 0.304 and the critical ratio $t$-value is 5.022 which is significant. In view of this, it is concluded that intrinsic motivation, extrinsic motivation, self efficacy and time management have positive influence and impact on students' performance in online distance learning. The above results well supported by the findings from previous studies which showed that the four factors of extrinsic motivation, intrinsic motivation, self-efficacy and time management have positive and significant influence on students' performance. From the structural path analysis, it clearly shown that time management has a stronger influence on the students' performance with a path coefficient of 0.304 . Therefore, more emphasis should be given to guide the online distance learning students to on how to manage their time in their study. Then, the focus should also be given in motivating the students intrinsically and extrinsically 
in their study since the path coefficients of 0.206 and 0.298 respectively for intrinsic and extrinsic motivation which show positive and significant influence of students' performance. The findings of this study suggested that a student's performance in online distance learning institutions can be strengthened and enhanced by emphasising the factors that can boost intrinsic motivation, extrinsic motivation, self efficacy and time management. Conversely, online distance learning students' performance can be reinforced and enhanced by increasing the level of intrinsic motivation, extrinsic motivation, self efficacy and time management. Ultimately, students' performance in online distance learning should play an important role in reducing the university's students' attrition rate.

\section{CONCLUSION}

In conclusion, the findings of this study also support the findings from Wei, Tuan Sulaiman, Mohamad and Abu Kassim (2011) who found that learners also had problems in terms of their time as they are all full-time working adults. Many students studied at night and whenever they can, although some had fixed study routine. Therefore, it is recommended that the university could include a time management session for the students as this would assist them in managing their studies. The limitation of this study, the focus is only on online distance learning students in Klang Valley due to time and other constraints. For future research, it is recommended students from other online distant learning institution be included in sample selection.

\section{REFERENCES}

Artino, A. R. (2008). Motivational beliefs and perceptions of instructional quality: Predicting satisfaction with online training. Journal of Computer Assisted Learning, 24(3), 260-270. https://doi.org/10.1111/j.1365-2729.2007.00258.x

Bandura, A. (1986). Social foundations of thought and action: A social cognitive theory. Englewood Cliffs, NJ: Prentice Hall.

Bates, A. W. (2005). Technology, e-learning and distance education (2nd ed.). New York: Routledge Falmer.

Carr, S. (2000, 11 February). As distance education comes of age, the challenge is keeping the students. The Chronicle of Higher Education, p. A39.

Dalton, J. P., Manning, H., Hagen, P. R., Paul, Y., \& Tong, J. (2000). Online training needs a new course. Cambridge, MA: Forrester Research.

Deci, E. L., \& Ryan, R. M. (2000). The 'what' and 'why' of goal pursuits: Human needs and the self-determination of behavior. Psychological Inquiry, 11(4), 227-268. https://doi.org/10.1207/S15327965PLI1104_01 
Fornell, C., \& Larcker, D. F. (1981). Evaluating structural equation models with unobservable variables and measurement error. Journal of Marketing Research, 18, 39-50. https://doi.org/10.1177/002224378101800104

Gallo, M., \& Ronaldo, V. (2011). Intrinsic versus extrinsic motivation: A study of undergraduate student motivation in science. Teaching \& Learning, 6(1), 95-106. https://doi.org/10.26522/tl.v6i1.379

Gudergan, S. P., Ringle, C. M., Wende, S., \& Will, A. (2008). Confirmatory tetrad analysis in PLS path modeling. Journal of Business Research, 61(12), 1238-1249. https://doi.org/10.1016/j.jbusres.2008.01.012

Hulland, J. S. (1999). Use of partial least squares (PLS) in strategic management research: A review of four recent studies. Strategic Management Journal, 20(4), 195-204. https://doi.org/10.1002/(SICI)1097-0266(199902)20:2\%3C195::AID-SMJ13 \%3E3.0.CO;2-7

Jung, I., \& Rha, I. (2000). Effectiveness and cost-effectiveness of online education: A review of the literature. Educational Technology, 40(4), 57-60.

Larreamendy-Joerns, J., \& Leinhardt, G. (2006). Going the distance with online education. Review of Educational Research, 76(4), 567-605. https://doi.org/10. 3102/00346543076004567

Martens, R. L., Gulikers, J., \& Bastiaens, T. (2004). The impact of intrinsic motivation on e-learning in authentic computer tasks. Journal of Computer Assisted Learning, 20(5), 368-376. https://doi.org/10.1111/j.1365-2729.2004.00096.x

Miltiadou, M., \& Savenye, W. C. (2003). Applying social cognitive constructs of motivation to enhance student success in online distance education. Educational Technology Review, 11(1), 78-95.

Nunnally, J. C. (1978). Psychometric theory. New York: McGraw-Hill.

Olson, T. M., \& Wisher, R. A. (2002). The effectiveness of web-based instruction: An initial inquiry. International Review of Research in Open and Distance Learning, 3(2). Retrieved 23 February 2003, from http:/www.irrodl.org/content/v3.2/olsen. html. https://doi.org/10.19173/irrodl.v3i2.103

Ringle, C. M., Wende, S., \& Will, A. (2005). SmartPLS 2.0. Hamburg. http://www. smartpls.de (Software).

Rumble, G., \& Latchem, C. (2004). Organisational models for open and distance learning. Policy for open and distance learning. In H. Perraton, \& H. Lentell (Eds.), Policy for open and distance learning (pp. 117-140). London: Routledge Falmer. https://doi.org/10.4324/9780203464403_chapter_7

Shroff, R. H., Vogel, D., Coombes, J., \& Lee, F. (2007). Student e-learning intrinsic motivation: A qualitative analysis. Communications of the Association for Information Systems, 19, 241-260.

Tallent-Runnels, M. K., Thomas, J. A., Lan, W. Y., Cooper, S., Ahern, T. C., Shaw, S. M., \& Liu, X. (2006). Teaching courses online: A review of the research. Review of Educational Research, 76(1), 93-135. https://doi.org/10. 3102/00346543076001093. 
Xie, K., DeBacker, T. K., \& Ferguson, C. (2006). Extending the traditional classroom through online discussion: The role of student motivation. Journal of Educational Computing Research, 34(1), 67-89. https://doi.org/10.2190/7BAK-EGAH3MH1-K7C6

Yukselturk, E., \& Bulut, S. (2007). Predictors for student success in an online course. Educational Technology \& Society, 10(2), 71-83. Retrieved from http://www. ifets.info

Wei, L. S., Tuan Sulaiman, T. S., Mohamad, W., \& Abu Kassim, Z. (2011). Motivation and study habits of working adults: A case study of Masters students in Open University Malaysia. Paper presented at the Conference Proceedings in International Conference Lifelong Learning, Seri Pacific, Kuala Lumpur, 14-15 November. 